\title{
Agronomic Management and Interventions to Increase Rice Yield in Bangladesh
}

\author{
M K A Bhuiyan ${ }^{*}$, A K M S Islam², M A R Sarkar ${ }^{3}$, M A A Mamun", M U Salam5 and M S Kabir ${ }^{6}$
}

\begin{abstract}
Avenues of agronomic manipulation need to be explored critically for getting potential rice yield in a given environment. Increasing population, decreasing resources and increasing climate vulnerability such as salinity, drought, submergence, early flash flood in haor areas can interrupt achieving the target of rice yield. Location specific variety, profitable cropping sequences, innovative and smart cultural management, and appropriate agronomic management with smart dissemination using multiple means would maximize rice yield and decrease the production barriers of rice. Appropriate variety and location- specific crop management systems should be formulated for rice yield maximization to reduce yield gap in farmers' field. A number of approaches can be undertaken for maximizing rice yield by adopting location-specific crop production e.g., manipulating sowing and planting times, appropriate weed management technology in proper time, suitable variety selection for improving cropping intensity, Judicious and balance application of organic and inorganic fertilizer application etc. Nitrogen application before panicle primordia is crucial because at this stage panicle primordia determined the spikelet number of the panicle and the absorbed nitrogen is efficiently used to increase spikelet number, accumulated photosynthates to leaf sheath and culm and, hence, increases panicle size and grain yield. Farmers should have a plan and should follow different steps of rice production to get higher yield and sustain productivity. Rice growth stage- wise agronomic management should be followed to get maximum yield. Choice of appropriate variety in a specific location or ecosystem is a major concern that contributed about $20 \%$ to the grain yield. Whereas management is a big issues which contributed about $60 \%$ for obtaining higher grain yield.The difference of environment $x$ management explained the largest variations $(80 \%)$ in explaining the yield. The bridging of knowledge gaps can bridge yield gaps. New paradigms need to be added to transfer and use new high yielding varieties and knowledge based technologies under new policy settings.
\end{abstract}

Key words: Rice production, yield gap, agronomic management

\section{INTRODUCTION}

The almost uneven topography and humid tropical climate of the country with abundant monsoon rain offer a unique environment for the rice plant in Bangladesh. The rice-growing environment of the country has been classified into three major ecosystems based on physiography and land types.These are a) irrigated b) rainfed, and c) floating or deepwater ecosystems.The rainfed ecosystem has been further classified as rainfed lowland and rainfed upland. Thus, all rice varieties cultivated inthe country are grouped into five distinct ecotypes such as a) Boro, b)
Transplanted Aus (T. Aus), c) Transplanted Aman (T. Aman), d) Upland Aus (direct seeded Aus), and e) Deepwater rice (Floating rice).Boro rice is grown completely under the irrigated ecosystem during the dry period (October/November to June/July) while T. Aman (July to December), T. Aus (during March/April to August) and Upland rice (March to July) are grown under the rainfed ecosystem to maintain the current production level and to feed the extra population in the future rice production(Fig 1.). Increasing rice production further is a gigantic task since there is no scope for horizontal expansion of the rice

\footnotetext{
${ }^{1}$ Agronomy Division, Bangladesh Rice Research Institute (BRRI), Gazipur-1701, Bangladesh; ${ }^{2}$ Farm Machinery and Postharvest Technology Division, BRRI, Gazipur-1701, Bangladesh; ${ }^{3}$ Agricultural Economics Division, BRRI, Gazipur1701, Bangladesh; ${ }^{4}$ Agricultural Statistics Division, BRRI, Gazipur-1701, Bangladesh; ${ }^{5}$ Freelance International Consultant (Agricultural Systems), Bangladesh; ${ }^{6}$ Director General, BRRI, Gazipur-1701, Bangladesh.

*Corresponding author's E-mail: bhuiyanbrri@gmail.com (M K A Bhuiyan)
} 
area due to the gradual diminishing of cultivated land as a result of diverting its uses for houses, roads, industries and urbanization (Sattar, 2000). We have to cope up with different stresses like salanity, submergence, drought, cold, high temperature and flsah flood manipulating and tailoring agronomic management to enable the rice farmers to adopt an uncertain future climate change based on research supported data by researchers and different stakeholders (Fig.1).

The population of Bangladesh will reach 215.4 million in 2050, when 44.6 MT (million ton) of clean rice will be required (Kabir et al., 2015). Bangladesh is losing arable lands about 220 hectares per day, equivalent to $1 \%$ of the country's cultivable land per year. The government, therefore, considers food and nutrition security as a key means for the country's economic growth, with a view to becoming a middle income country by 2025 . The yield gap of rice production is 0.83 tha $^{-1}$ $(20.7 \%)$ between actual farm yield and potential farm yield in Bangladesh (Kabir et.al, 2015). If this yield gap could be reduced @ $1.135 \%$ year-1, 4.8 MT rice surplus can be achieved in 2050. Reducing the yield gap of 10$15 \mathrm{~kg}$ year $^{-1} \mathrm{ha}^{-1}$ would provide a surplus of 3.07 MT in the year 2041(Kabir et al., 2015).
Our vision is sustainable food, nutritional and livelihood security, and maintains rice production level to feed the increasing people of Bangladesh. Our mission is to develop and disseminate eco-friendly technologies to enhance the productivity, profitability, and sustainability of rice cultivation. Agronomy, a prime discipline in the field of agriculture, can play an important role in elevating and sustaining rice production in Bangladesh. According to rice vision (Kabir et al., 2015), the current population of 162 million will rise to 171 million in 2021, near 200 million in 2030 and across 200 million in 2040, and reach 215 million in 2050. Accordingly, the production demand of clean rice will go up to 38.83 MT in 2031 which is $10 \%$ more compared to the current production level. Increasing rice production further is a gigantic task since there is no scope for horizontal expansion of the rice area due to the gradual diminishing of cultivated land as a result of diverting its uses for houses, roads, industries, and urbanization.Three interventions to be employed in order to maintain the current momentum of rice production in Bangladesh (Kabir et al., 2015). These are: (i) accelerating genetic gain, (ii) minimizing yield gap, and (iii) curtailing adoption lag of rice varieties in the field.

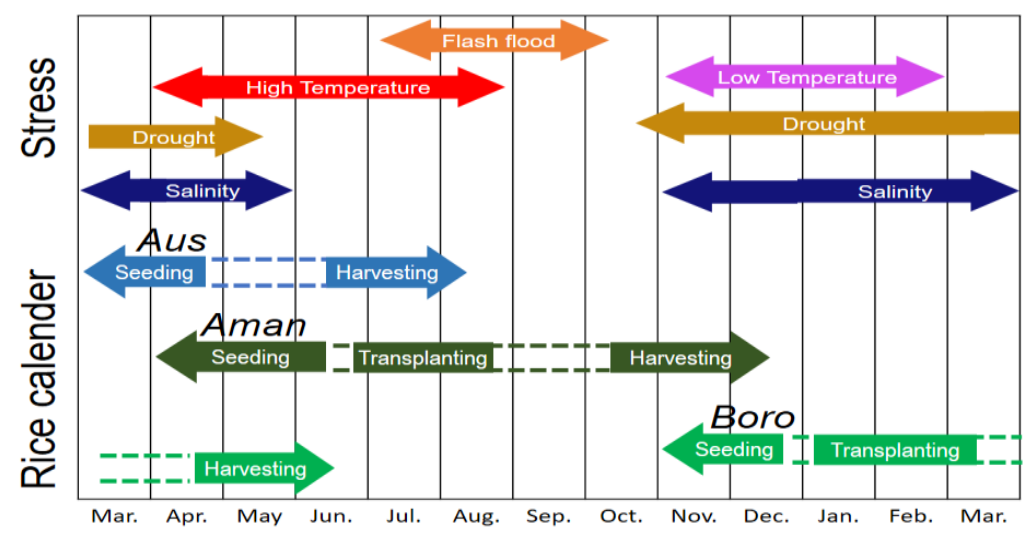

Source: Adopted and modified from Shelley et. al.,2016

Fig. 1. Agroclimatic conditions and rice calendar of Bangladesh (The above block arrows indicate the different kinds of stresses induced by the agroclimatic parameters throughout the year and the lower block arrows with dashes represents the rice crop calendar of Bangladesh).

162 Bhuiyan et al. 
Specific input and agricultural management strategies are required to achieve the potential production by overcoming biophysical and socioeconomic constraints causing yield gaps (Pradhan et al., 2015). The management strategies include: fertilizers, pesticides, advanced soil management, land improvement, ecosystem based production management and improving market convenience for growers. Therefore, options available for increasing rice production are a) a breakthrough in the present yield potential of the varieties, b) full exploitation of the present yield potential of the existing modern varieties; and, c) utilization of unfavourable but potential ecosystems for rice and or other systems of food production (Sattar, 2000).

This paper will elaborate on the possibility and means of exploiting the yield potential of the existing modern rice varieties and problems as well as the way of minimizing of rice yield gap at the farmers' level.

With the above background, the article undertook three specific objectives in relation to specific agronomic management.

i. Presentation of changing status of different agronomic management practices

ii. Highlighting the scenarios of yield loss associated (projected and actual) with several agronomic management; and,

iii. Development and mapping the action plan for three decades on reducing yield loss from different agronomic management.

\section{MATERIALS AND METHODS}

Yield loss from different agronomic management practices was considered through a discussion meeting with a group of agronomists, statisticians, and other scientific personnel with the help of current secondary and reviewed data. It was assumed that realistic yield loss from different agronomic management (time of planting, seedling age, spacing, fertilizer, weed, transplanting depth, and others) was $15.35 \%$. The projection was made from current status of rice production, yield loss due to improper management practices and minimization of yield loss up to $10 \%$. It was reviewed from different experimental data that different agronomic management like use of aged seedling, inappropriate time of planting, spacing, imbalance fertilizer application, weed, seed quality and tillage may reduce a certain level of yield. Yield loss projection from different agronomic management was calculated from the baseline yield loss quantity. Table 1 presents the baseline yield loss data (Kabir et al., 2020).

Table 1. Yield loss (\%) due to different agronomic factors.

\begin{tabular}{ll}
\hline Agronomic factor & Yield loss (\%) \\
\hline Time of sowing/transplanting & 4.75 \\
Seedling age & 2.50 \\
Spacing & 1.20 \\
Weeds & 1.90 \\
Fertilizer (dose and timing) & 4.00 \\
Other agronomy management (seed & 1.00 \\
quality, tillage etc) & \\
Total & 15.35 \\
\hline
\end{tabular}

Source: Adopted from Kabir et al., 2020

\section{RESULTS AND DISCUSSION}

\section{Agronomy and its contribution in enhancing the yield}

The ultimate goal of any farmer is to get maximum yield per unit area. The low yield on the farmer's field could be ascribed to the failure of the farmers to adopt and practice the recommended agronomic practices that govern the production of the crop. Table 2 shows the role of agronomic management in grain yield which is described by Salam et al., 2016. Choice of appropriate variety in a specific location or ecosystem is a major concern that contributed $20 \%$ to the grain yield. Whereas management is a big issue which contributed $60 \%$ for obtaining higher grain yield. However, it is the largest variation of environment $\times$ management that explained the largest variation (80\%) in explaining the yield. The classical equation of yield is $\mathrm{y}=\mathrm{G} \times \mathrm{E} \times \mathrm{M} \times \mathrm{P} \ldots \ldots$..Eq. 1 (Salam et 
al.,2016). Where " $G$ " is the genotype or variety of a crop and " $E$ " is the environment on which the variety is set to express its potential( Eq.1). In recent years, the " $\mathrm{E}$ " component has been segregated to " $\mathrm{E}$ " by " $\mathrm{M}$ ", where " $\mathrm{M}$ " is management.This segregation has been necessary because the whole atmosphere of the environment (E) is changed due to management (M). It has been added another component " $\mathrm{P}$ " to this equation( Eq.1). Here " $\mathrm{P}$ " stands for people and very simultaneously, management is run by the efficiency of people involved. For example; with the same prescribed management system, two fields sitting side by side can perform differently because of farmers' (" $\mathrm{P}^{\prime \prime}$ ) personal efficiency. Personal efficiency depends on timely planning, organizing the product materials, leading to distribute of inputs and control the farm from any kind of stress. The non-G component largely belongs to "Agronomy".

Table 2. Variety, management and environmental effect on yield of rice.

\begin{tabular}{|l|l|l|}
\hline Component & Sub component & $\%$ yield depends \\
\hline $\begin{array}{l}\text { Genotype/ } \\
\text { Variety(G) }\end{array}$ & - & 20 \\
\hline Management(M) & $\begin{array}{l}\text { Technical } \\
\text { knowledge and } \\
\text { Personal } \\
\text { efficiency(P) }\end{array}$ & 60 \\
\hline Environment(E) & - & 20 \\
\hline Total & - & $100 \%$ \\
\hline
\end{tabular}

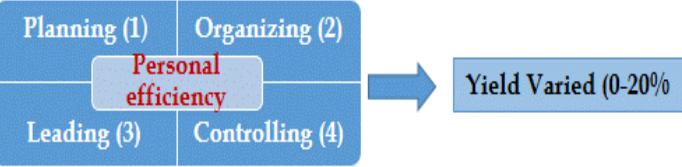

Source: Adopted and modified from Salam et al., 2016

\section{Generic yield loss management options}

Management factors that pull down farmlevel yield in different rice ecosystems in different growing seasons and plan for reduce yield

a. Delay of sowing/transplanting. Planting of rice becomes late resulting in a reduction of yield at the rate of 60.0, 55.4, and $9.6 \mathrm{~kg} \mathrm{ha}^{-1}$ for each day delay during Boro, Aus, and Aman seasons, respectively (Table 3). Table 3 indicates projected yield loss (\%) due to wrong sowing/transplanting time and minimization of yield loss with practicing recommended sowing/transplanting time.It is possible to add a significant amount of clean rice through maintaining timely sowing and transplanting.

Farmers often cannot follow the appropriate cropping system due to the shortage of draft power, unavailability of labor due to the sudden high demand during the peak period when farm activities overlap across the seasons. Time of planting, optimum seedling age, seeding time, and transplanting time should be maintained properly based on season, ecosystem, and growth duration of rice varieties. Otherwise significant yield loss will have occurred.

Because of the delay in Boro, the crop may face an early/flash flood and may be damaged. If delay in Aman, the yield will be decreased due to incomplete vegetative growth, in the immaturity stage and variety may fall in cold and sterility may be increased. If delay in Aus, Aman will be delayed and the yield will be decreased. If early in Aman, pest infestation will be high and yield will be decreased. If early in Aus, it will be in high temperature and sterility. If early in Boro, it will be in low temperature and sterility. So optimum and recommended planting time with optimum seedling age is a prerequisite to get a higher yield. Table 4 and 5 present seasons and ecosystem-based recommended seeding and transplanting time and seedling age.

b. Use of unhealthy seed. Poor quality seeds produce unhealthy plants resulted in poor growth and development and decrease grain yield.Using cleaned and quality rice seeds increased grain yield, enhanced crop growth, and also reduced damage from weeds, insect pests, and diseases. 
Table 3. Yield reduction due to increased seedling age.

\begin{tabular}{lll}
\hline Season & $\begin{array}{l}\text { Recommended } \\
\text { seedling age (day) }\end{array}$ & $\begin{array}{l}\text { Yield reduction with the increase of } \\
\text { seedling age }\left(\mathrm{kg} \mathrm{ha}^{-1} \mathrm{day}^{-1}\right)\end{array}$ \\
\hline Boro (normal) & $40-45$ & $24-40$ \\
Boro (cooler areas) & $50-55$ & $2-125$ \\
T. Aus & $15-30$ & $1-37$ \\
T. Aman (normal) & 30 & $2-77$ \\
T. Aman (late and very late) & $45-50$ & 1 to more than 71 \\
\hline
\end{tabular}

Source: Ahmed et al., 2006: BRRI-DAE technology transfer workshop paper (2006)

Table 4. Season wise and ecosystem-based seeding, transplanting and seedling age of rice in Boro and Aus seasons.

\begin{tabular}{|c|c|c|c|c|c|}
\hline \multirow[t]{2}{*}{ Season } & \multirow[t]{2}{*}{ Ecosystem } & \multirow[t]{2}{*}{ Agricultural region } & \multicolumn{2}{|c|}{ Appropriate seeding time } & \multirow{2}{*}{$\begin{array}{l}\text { Seedling age } \\
\text { (day) }\end{array}$} \\
\hline & & & $\begin{array}{l}\text { Short duration } \\
\text { variety }\end{array}$ & $\begin{array}{l}\text { Long duration } \\
\text { variety }\end{array}$ & \\
\hline \multirow[t]{6}{*}{ Boro } & Favourable & All region & 15-21 Nov & 1-7 Nov & $35-45$ \\
\hline & Haor region & $\begin{array}{l}\text { Kishoreganj, } \\
\text { Netrakona, Sylhet, } \\
\text { Sunamganj, Habiganj, } \\
\text { B. Baria and } \\
\text { Moulavibazar }\end{array}$ & 15-21 Nov & 1-7 Nov & \\
\hline & Cold prone region & $\begin{array}{l}\text { Greater Rangpur and } \\
\text { Rajshahi }\end{array}$ & 1-15 Dec & 20 Nov-7 Dec & \\
\hline & Submerge area & $\begin{array}{lr}\text { Greater } & \text { Cumilla, } \\
\text { Khulna, } & \text { Jashore } \\
\text { (Vhobodaho) } & \end{array}$ & 7-21 Nov & $1-10 \mathrm{Nov}$ & \\
\hline & Salinity area & Coastal area & 1-15 Nov & - & \\
\hline & BROUS (Late Boro) & Greater Rangpur & $15-28 \mathrm{Feb}$ & - & \\
\hline \multirow[t]{2}{*}{ Aus } & Broadcast & Aus growing region & 30 Mar-15 Apr & - & - \\
\hline & Transplant & Aus growing region & 1-30 Apr & - & $15-20$ \\
\hline
\end{tabular}

c. Over-aged seedling. Over-aged seedlings of rice reduce a significant amount of yield which varies over the season. Yield reduces significantly because of per day increase in seedling age. Transplanting optimum seedling age should be practice gradually in all regions depending on rice variety, season, and ecosystem.

d. Imbalanced use of fertilizers and other inputs. Imbalanced use of N, P, K, S, Zn fertilizer affect the growth and development of rice and induces disease and insect development. Especially farmers fail to apply urea fertilizer timely with accurate dose. As a result, reduced spikelet number per unit area and consequently reduce grain yield. By adopting balanced fertilizer and applying urea timely and accurately grain yield will be increased significantly.

e. Weed management. Failure to control weeds during the critical competition period decrease a significant amount of grain yield. Commonly recommanded weed management options are herbicide $\mathrm{fb}$ $1 \mathrm{HW}, 2 \mathrm{HW} / 3 \mathrm{HW}$ and mechanical weeding $\mathrm{fb} 1 \mathrm{HW}$. Weed management by any means within critical period is crucial for effective weed management in rice. Because it has been estimated that rice yield decreases by $0.75-1.00 \mathrm{~kg}$ for every $1 \mathrm{~kg}$ of weed biomass produced (IRRI,2003). 
Table 5. Season wise and ecosystem-based seeding, transplanting and seedling age of rice in Aman season.

\begin{tabular}{|c|c|c|c|c|c|}
\hline $\begin{array}{l}\text { Agricultural } \\
\text { region }\end{array}$ & $\begin{array}{l}\text { Characteristic of } \\
\text { variety }\end{array}$ & $\begin{array}{l}\text { Seeding } \\
\text { time }\end{array}$ & $\begin{array}{l}\text { Transplanting } \\
\text { time }\end{array}$ & $\begin{array}{l}\text { Seedling } \\
\text { age (day) }\end{array}$ & Comment \\
\hline $\begin{array}{l}\text { Greater } \\
\text { Rangpur and } \\
\text { Bagura region }\end{array}$ & Short duration & $\begin{array}{l}5^{\text {th }} \text { Jul- } \\
5^{\text {th }} \text { Aug }\end{array}$ & $\begin{array}{l}25 \text { Jul- } \\
25 \text { Aug }\end{array}$ & $15-20$ & $\begin{array}{l}\text { If seedling age }>20 \text { days, } \\
\text { reduce tillering and grain } \\
\text { yield. Transplanting before } 25 \\
\text { Jul- } 25 \text { Aug attack by rat and } \\
\text { birds. }\end{array}$ \\
\hline $\begin{array}{l}\text { Flood prone } \\
\text { and lowland }\end{array}$ & $\begin{array}{l}\text { Late photosensitive } \\
\text { variety }\end{array}$ & $\begin{array}{l}10 \text { Jun- } \\
5 \text { Aug }\end{array}$ & $\begin{array}{l}20 \text { Jul- } \\
15 \text { Sep }\end{array}$ & $35-40$ & $\begin{array}{l}\text { Late and long duration } \\
\text { photosensitive variety. }\end{array}$ \\
\hline $\begin{array}{l}\text { Salinity tolerant } \\
\text { variety }\end{array}$ & Coastal area & $\begin{array}{l}20 \text { Jun- } \\
25 \text { Jul }\end{array}$ & $\begin{array}{l}25 \text { Jul- } \\
30 \text { Aug }\end{array}$ & $30-35$ & $\begin{array}{l}\text { BRRI dhan } 40,41,54 \text { varieties } \\
\text { could be planted up to } 15 \text { Sep. }\end{array}$ \\
\hline
\end{tabular}

f. Spacing and other agronomic management. Optimum plant population per unit area is a prerequisite for obtaining a higher yield of rice. Farmers failure to maintain proper spacing, caused a reduction of yield. On the other hand poor land preparation and higher transplanting depth which are also the causes for yield reduction in the farmers' field. During seedling uprooting, if the soil is dry roots of the seedling may injured, and decreased seedling quality and delayed transplanting shock, and may reduce grain yield. Maintaining proper spacing and good land preparation with optimum transplanting depth $(2-3 \mathrm{~cm})$ could add extra yield. Fertilizer largely contributes to rice yield in all the ecosystems followed by weed control. Moreover, rice yield decline due to over-mining of soil nutrients, organic matter depletion, floods and droughts, and the use of poor-quality seed.

\section{Fundamentals of yield loss and management}

\section{Narrowing the yield gap}

Yield/efficiency gap was defined as the difference between achieved yield/efficiency and potential yield/efficiency (Van Ittersum et al. 2013). The achieved yield can be measured directly, while the potential yield of a certain region can be simulated by a model. A proportion of $80 \%$ of the potential yield should be considered as the attainable yield (Cassman et al. 2003). Resource use efficiency (e.g., nitrogen, water and solar radiation) was defined as the amount of output achieved per unit input. Rong et al., (2021) comprehensively review the currently available studies on yield and efficiency gaps for the world's major food crops in recent years. Based on more than 110 published papers, data from FAO and the Global Yield Gap and Water Productivity Atlas, Rong et al.,(2021) summarize the concepts, quantitative methods for gap analysis, yield limiting factors, and resource utilization efficiency of wheat, maize and rice (Bin and Ying, 2021).

In Bangladesh yield can be minimized following the model with different site specific and season wise approprite agronomic management and through properly addressing the stress prone area and promoting the integrated management plan. Rice growth stage based management 
practice and some necessary steps should be followed properly.

\section{Considering figure 2, the following points to be considered to curtail the rice yield gap}

- Timely seeding/ transplanting with optimum seedling age and spacing.

- Balanced fertilizer application (especially urea in time) and weeding in a critical period.

- Selection of shorter duration rice varieties with high yield potential to fit into the farmer's cropping pattern.

- To sustain soil productivity a programme regarding integrated use of organic and inorganic fertilizers should be undertaken.

- Strengthen the present linkage between research and extension to accelerate the dissemination of site-specific agronomic management among the farmers.

- Increase the yield by improving soil health, nutrient use efficiency, using efficient varieties.

- A synergy between agronomic technologies with soil and water, extension activities to bridge the yield and information gaps (Field days, adoption), the policy of governance, etc is needed.

\section{Site-specific and season wise agronomic management}

Smart technology such as location-specific variety, profitable cropping sequences, innovative cultural management, and appropriate agronomic management with smart dissemination using multiple means would maximize rice yield and minimize production barriers of rice. It is observed from different experimental results that rice yield could be increased by $0.74 \mathrm{t} \mathrm{ha}^{-1}$ by adopting proper agronomic management (Bhuiyan et al., 2017). Site-specific nutrient management improved productivity and profitability in rainfed lowlands of the Philippines and get 6\% more yield and reduce nitrogen use in the farmers' field (Banayo et al.,2018). Applying alternative fertilization practices like slow-release nitrogen fertilizer, organic fertilizer, straw return, green manure, instead of conventional fertilizers might improve rice yield and nutrient use efficiency in rice cropping systems in China. Furthermore, the recovery efficiency (REN), agronomic efficiency (AEN), and the partial factor productivity of nitrogen (PFPN) were increased by $6.0-34.8 \%, 10.2-29.5 \%$, and $4.7-$ $6.9 \%$, respectively under the alternative fertilization options relative to conventional fertilization (Ding et al., 2018). Fertilizer, seed, and pesticide use can be reduced in intensive lowland irrigated rice by following best management practices without yield penalty. In Thailand, it is found that the improved best management practice reduces cost by $26 \%$ and increases the profit of rice production (Stuart et al., 2018). The adoption of these practices can lead to a more economically, environmentally, and socially acceptable rice production situation in Bangladesh.

Integrative and optimized crop management techniques, i.e., optimized density, optimizing $\mathrm{N}$ application and applying $\mathrm{N}$ at later growth stage, alternate wetting and moderate soil drying, applying rapeseed cake fertilizer, applying organic manure could achieve the dual goal of increasing grain yield and resource use efficiency through improving agronomic and physiological performances, especially increases in sink size and shoot and root growth, leading to higher grain yield and NUE, (Depeng Wan et al., 2017; Zhang et al., 2018). 


\begin{tabular}{|c|c|c|c|c|c|c|c|c|}
\hline \multirow{7}{*}{$\begin{array}{l}\text { Simulated } \\
\text { potential } \\
\text { yield }\end{array}$} & \multicolumn{6}{|c|}{$\begin{array}{l}\text { Yield limiting/ reducing factors not controlled at the research } \\
\text { station }\end{array}$} & \multirow{2}{*}{\multicolumn{2}{|c|}{\begin{tabular}{|l|} 
Yield GAP-0 \\
Yield GAP-1 \\
\end{tabular}}} \\
\hline & \multirow{6}{*}{$\begin{array}{l}\text { Experimental } \\
\text { maximum } \\
\text { yield } \\
\text { ( Exploitable } \\
\text { yield) } \\
80 \% \text { of } \\
\text { potential } \\
\text { yield }\end{array}$} & \multicolumn{5}{|c|}{$\begin{array}{l}>\text { Nontransferable technology } \\
>\text { Environment and management constraints }\end{array}$} & & \\
\hline & & \multirow{5}{*}{$\begin{array}{l}\text { Technical } \\
\text { yield } \\
\text { ( Potential } \\
\text { farm } \\
\text { yield/ } \\
\text { Attainable } \\
\text { yield }\end{array}$} & \multicolumn{4}{|c|}{$>$ Resource use efficiency } & \multirow{3}{*}{$\begin{array}{l}\text { Yield } \\
\text { GAP-2 }\end{array}$} & GAP2A \\
\hline & & & \multirow[t]{4}{*}{$\begin{array}{l}\text { High yield } \\
\text { high } \\
\text { efficiency }\end{array}$} & \multicolumn{3}{|c|}{$\begin{array}{l}>\text { Market access } \\
>\text { Diminishing return } \\
>\text { Price }\end{array}$} & & GAP2B \\
\hline & & & & \multirow[t]{3}{*}{$\begin{array}{l}\text { Econo } \\
\text { mic } \\
\text { yield }\end{array}$} & \multicolumn{2}{|c|}{$\begin{array}{l}>\text { Lack of input } \\
>\text { Farmers' risk } \\
>\text { Aversion } \\
\text { strategies }\end{array}$} & & GAP2C \\
\hline & & & & & \multirow[t]{2}{*}{$\begin{array}{l}\text { Actual } \\
\text { yield }\end{array}$} & $\begin{array}{l}\text { Agrono } \\
\text { mic } \\
\text { mgt. }\end{array}$ & \multicolumn{2}{|c|}{ Yield GAP-3 } \\
\hline & & & & & & $\begin{array}{l}\text { Basic } \\
\text { yield }\end{array}$ & \multicolumn{2}{|c|}{$\begin{array}{l}\text { This level } \\
\text { changes with soil } \\
\text { and climate }\end{array}$} \\
\hline
\end{tabular}

Fig. 2. Yield gaps and their main constraints. Yield Gap-0 cannot be reduced; Yield Gap-1 is the gap between the yield produced at experimental station level and farmland level; Yield Gap-2 is the gap caused by different management practices at the farmland level; Yield Gap-3 is the gap between farmland and fallowland, and caused by water, fertilizer, and other management measures.

Yield reduction could be triggered by per day increased seedling age in a different season. If grwers planted older seedlings instead of recommended seedling age a significant grain yield reduction occurred. Yield reduction had been calculated per day based on increased seedling age $\left(\mathrm{kg} \mathrm{ha}^{-1}\right)$ in Boro season 24-40, cooler regions of Boro 2125, T. Aus 1-37, T. Aman 2-77 and late T. Aman 1-71 (Ahmed et al., 2006). So, appropriate variety and location-specific crop management systems should be formulated for yield maximization in rice to reduce the yield gap in farmers' fields. A number of approaches can be undertaken:

- Adopting location-specific crop production techniques.

- Manipulating sowing and planting times and use of optimum seedling age

Source: Modified from Ong Liang-bing et al.,2021 according to location-specific rice ecosystem and variety.

- Appropriate weed management technology in proper time.

- Suitable variety selection according to rice ecosystem and cropping pattern and for improving cropping intensity.

- Judicious and balance application of organic and inorganic fertilizer application.

Approaches for increasing and sustaining site-specific rice production and productivity of stress-prone area

Flash Flood, drought, and salinity are the main stress environments in Bangladesh where rice frequently suffers from considerable shock to maintain its full yield potential. The nature and extent of these environments vary with season, topography, and location. 


\section{Drought management strategy}

- BRRI scientists identified drought risks of varying intensities for medium duration (140 days) varieties.

- Transplanting between 5 July to 25 July might have less risk of encountering drought. Short duration (115-120 day) rice varieties like BRRI dhan66, BRRI dhan71, BRRI dhan75, BRRI dhan33, BRRI dhan39, Binadhan-7 could avoid the terminal drought if they are transplanted by 15 July in the drought-prone area.

- Some of the varieties like BRRI dhan56, BRRI dhan57, BRRI dhan62 can be grown within 100-110 days in order to escape drought.

- After harvesting these crops by midNovember, farmers can go for wheat and then mungbean cultivation.Therefore T.Aman (short duration)-WheatMungbean is an adaptable cropping pattern in a drought-prone area.

- The potentiality of T. Aman rice would be increased up to $30 \%$ provided the crop is satisfied with supplemental irrigation.This could be done by BRRI designated rainwater harvesting reservoir having the size of $4-5 \%$ of the command area.

Sustainable increase of rice production in Aus ecosystem require:

- Assurance of partial or supplemental irrigation facilities in Aus season to confirm the establishment of direct dry seeded Aus.

- Weed is a serious problem for directseeded Aus rice. So it needs attention for successful and economic weed management in direct-seeded rice.

- Location-specific varieties along with production technologies will be the crucial factors for attaining the goal.
- For timely establishment and post-harvest operations, farm mechanization needs to be emphasized.

- Some fallow areas in the South and Northeastern region should be brought under cultivation like Barishal and Sylhet region.

Sustainable increase of rice production in haor areas require:

- Some of the agronomic practices and varietal intervention might be helpful to reduce the growth duration of boro rice crop and increase grain yield.

- Cold-tolerant and short-duration rice varieties (120-135 days) need to be developed for the farmers in Haor regions which will be at least 15 days earlier than the existing common practice.

- Rice seedlings grown from an imposed high temperature (grown under polyethene cover) might have some more accumulated temperature at the seedling stage to reduce the growth duration to some extent.

- Direct seeding is another way to reduce the growth duration by about 2 weeks.

- Early seeding/transplanting can avoid flash floods in hour areas.

Recommended Strategies and way forward for sustainable increase of rice production in haor areas are given in figure 3.

Sustainable increase of rice production in coastal areas

Following agronomic practices might be helpful to reduce salinity:

- Winter is relatively short in the coastal region. So the establishment of Boro a month earlier might help to avoid higher salinity during April-May.

- Straw mulching conserves water and reduces the capillary rise of saline water 
and prevents forming the saline crust. Soil flashing (washing soil with fresh water) four times is good for reducing soil salinity during Boro season, one time flashing during the reproduction phase is quite useful for the crop. Integrated fertilizer management is quite beneficial for a growing crop in a saline-prone area. Dibbling rice seeds in Aus season help to avoid direct contact of seedling with saline crust at the upper layer of the soil.
- Cultivation of Dhaincha as a crop in $\mathrm{T}$. Aman-Fallow cropping pattern to reduce capillary movement of salty water through evaporation.

- Transplanting 45 - day- old seedlings with 3-4 seedlings hill-1 is recommended because the relatively aged seedlings attain tolerance at the late seedling stage.

- Nitrogen management with USG is another option to obtain a higher yield in T. Aman season in saline areas.

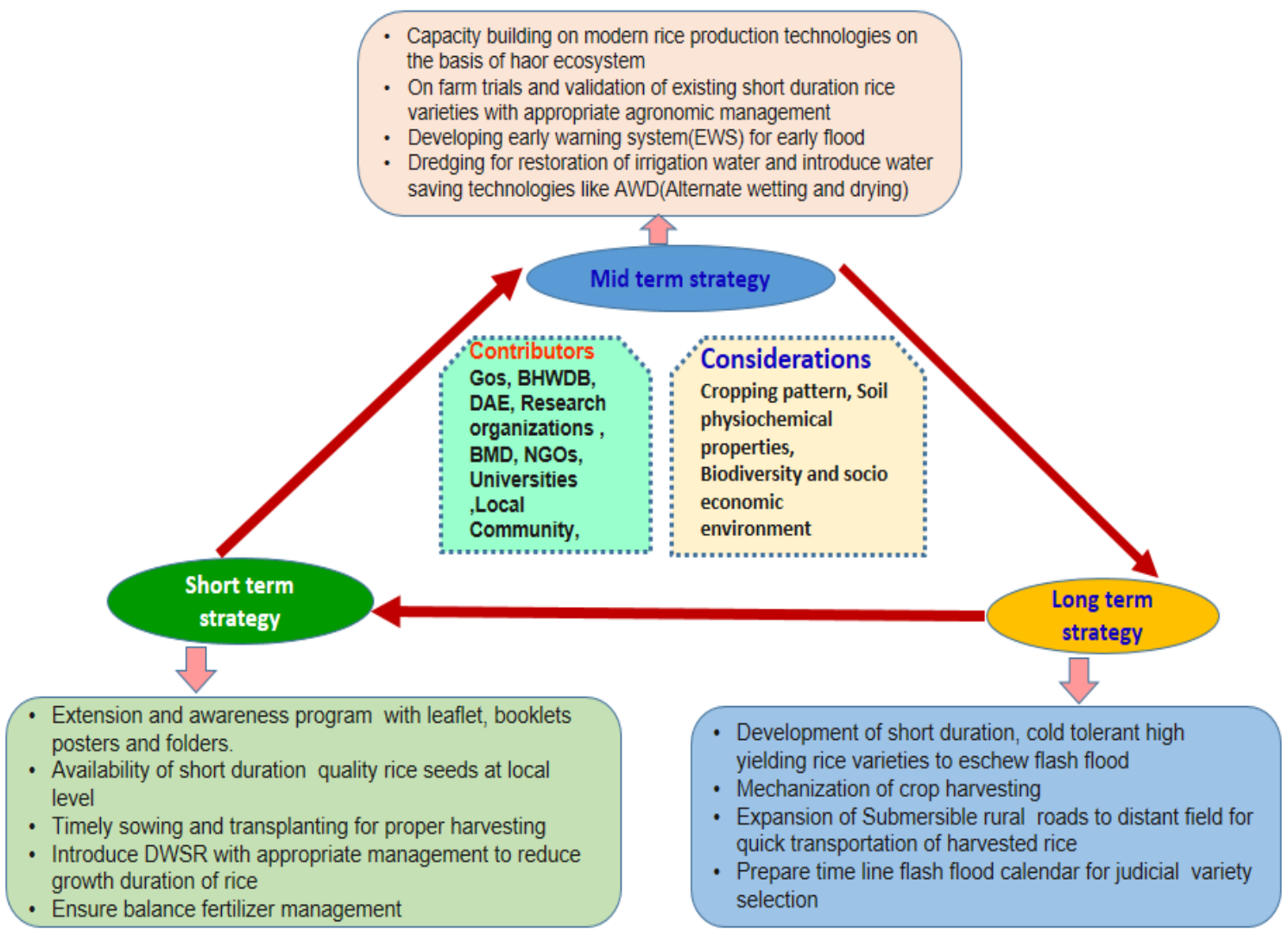

Fig. 3. Framework for sustainable increase of rice production in haor areas Source: Modified from Kamruzzaman and Rajib (2018) 
Fertilizer management strategy for sustainable rice production

The role of chemical fertilizer in rice yields is currently $59-69 \%$ only, but its use with organic nutrient sources can help in improving rice grain yield. The use of organic and inorganic nutrients is responsible for obtaining 0.78$117 \%$ higher yield compared to chemical fertilizer alone (Nahar et al., 2018). Application of biofertilizer along with $50 \%$ reduction of $\mathrm{N}$ and $\mathrm{P}$ produced $32 \%$ higher rice yield over chemical fertilizer (Nahar et al., 2018). Green manuring with sesbania improves soil carbon status and increases yield by $9-11 \%$ over chemical fertilizer.

Moreover, use of approaches for sustainable nutrient management (Fig.4) including appropriate soil testing technique, fertilizer sources (organic, inorganic, biofertilziers and nanofertilizers) and application method in right combination using site specific nutrient management will reduce the fertilizer losses with high NUE and economic yield. So sustainable and ecosystem-friendly rice production depends on the combined use of organic and inorganic fertilizer in the future.

\section{Promotion of integrated crop management plan (ICMP)}

Integrated crop management (ICM) is a approach farming that aims to balance production with economic and environmental considerations by means of a combination of measures including crop rotation, cultivations, appropriate crop varieties, and careful use of inputs. It combines the best of traditional methods with appropriate modern technology, balancing the economic production of crops with positive environmental management.

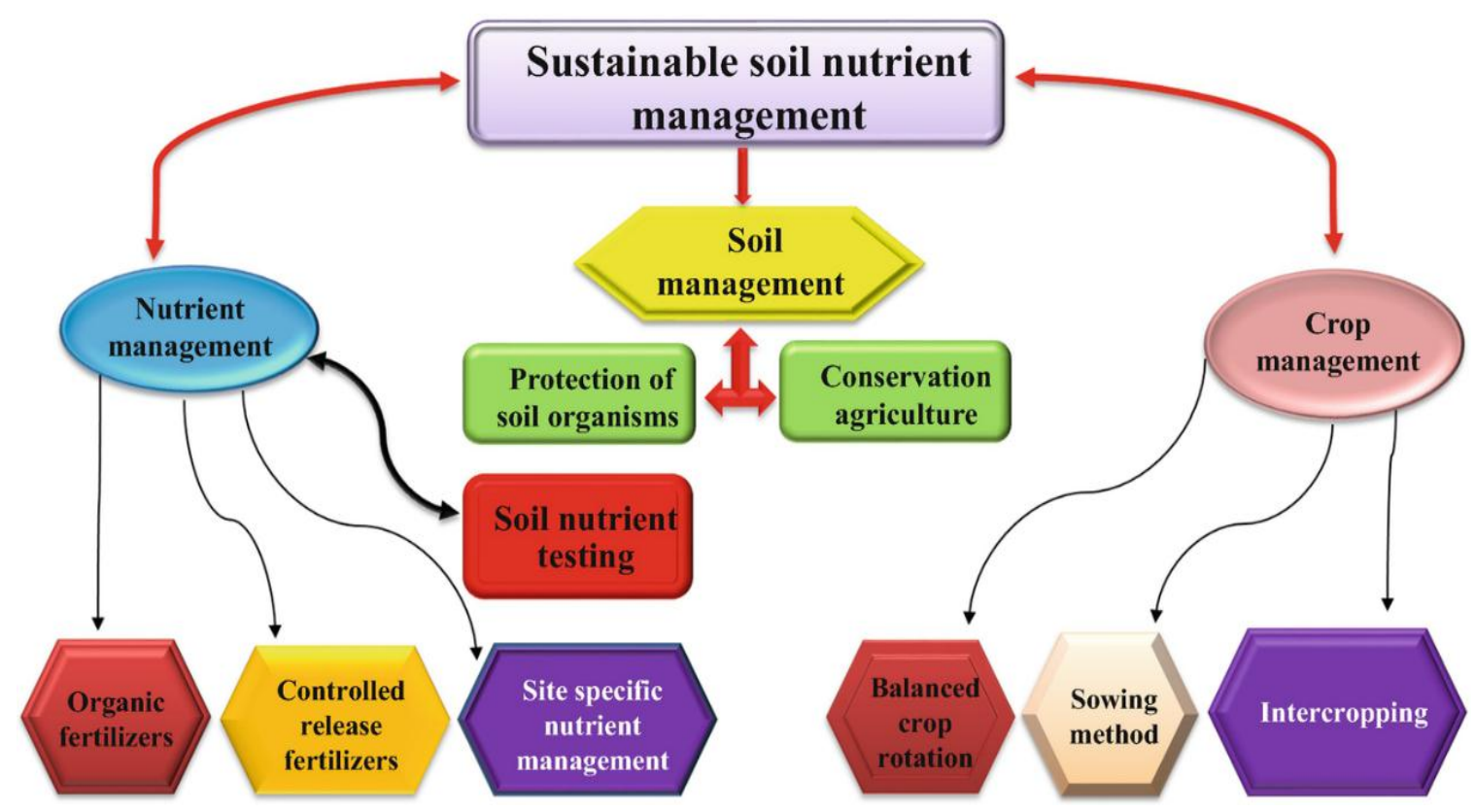

Fig. 4. Approaches for sustainable nutrient management

Source: Adopted from Rehman et al., 2019 
Basic components of ICM are crop management, nutrient management, pest management and financial management. Each of these components is associated with agricultural Best Management Practices (BMP). Each BMP overlaps between the broader components of ICM. In the end, ICM and subsequent improved use of on-farm resources cause a reduced dependency on outside inputs of fertilizers, pesticides, and herbicides through the integration of farm management components and best management practices.

A maximum rice grain yield of 9.40 and $10.53 \mathrm{t} \mathrm{ha}^{-1}$ was achieved under ICM in China (Depeng et al., 2017), indicating the potential to further increase the grain yield of rice following a holistic and integrated agronomic approach. Optimum crop management especially nutrient management has proven to be highly effective in improving rice grain yield. Other management practices such as planting methods and plant density, quality of seeds and seedlings, and irrigation regime can also affect grain yield to some extent. Depeng et al., 2017, stated that testing a single component of management practices independently may not capture the impact of a holistic package would have on enhancing rice grain yield. He stated that closing the yield gap is becoming increasingly difficult to achieve by using a component technology in isolation.

Suitable improved varieties and improved cultural practices including integrated pest management and integrated plant nutrition management are the main components of ICMP. A number of innovative technologies identified by CREMNET (Crop and Resource Management Network), IRRI, may provide effective tools to partly narrow yield gaps in rice production for small farmers in developing countries. CREMNET works on the chlorophyll meter technique, leaf color chart for field-specific $\mathrm{N}$ management, urea tablet deep placement, direct wet-seeding method, etc. (IRRI, 1997) and is appropriate for inclusion in integrated crop management packages to narrow gaps in rice production in developing countries.

\section{General steps for yield loss management}

To grow rice and get higher yield farmers should follow different steps. If farmers plan and follow the mentioned below steps, rice productivity will be increased (Table 6).

\section{Rice growth stage-wise agronomic management}

Each growth stages of rice requires some specific management practices. We have to follow the specific agronomic management to get higher yield and sustainable productivity (Table 7).

To achieve the target by 2020-2050, we have to settle a masterplan and accordingly we have to implement all those protocols step by step.

Location, variety and site specific smart agronomic management: Action Plan for each SABM (Stagewise Agronomic Broad
Management)

Table 7 presents rice stagewise agronomic management practices was. However, Table 8 indicates how this action plan will be implemented in a synchronized way by adopting different broad agronomic management. In this process in each growth stage and phase should have to perform some specific actions like framework development, screening, calibration, and technology validation. Therefore a mature smart agronomic management (Fig 5.) will be coming out. Continuous observation is needed on how these technologies are being performed. It will follow by massive demonstrations in the farmer's field and training for different stakeholders. It was explained how this action plan will work for a specific rice stage. 
Table 6. Steps to follow to obtain higher yield.

\begin{tabular}{|c|c|c|}
\hline & Step & Activity/Management \\
\hline i. & $\begin{array}{l}\text { Using } \\
\text { calendar }\end{array}$ & $\begin{array}{l}\text { A good crop calendar help the selection of a good variety in a cropping system and helps to } \\
\text { organize other farm activities in cropping sequences. }\end{array}$ \\
\hline ii. & $\begin{array}{l}\text { Choosing the best } \\
\text { variety }\end{array}$ & $\begin{array}{l}\text { It is required to select a variety according to rice ecosystem, cropping system and with high } \\
\text { yielding ability. }\end{array}$ \\
\hline iii. & $\begin{array}{l}\text { Using high-quality } \\
\text { seed }\end{array}$ & $\begin{array}{l}\text { It is needed to use quality seed, because it reduces the required seeding rate and produces } \\
\text { strong, healthy seedlings, resulting in a more uniform crop with higher yields. }\end{array}$ \\
\hline iv. & $\begin{array}{l}\text { Prepare and level } \\
\text { the fields well }\end{array}$ & $\begin{array}{l}\text { A well-prepared and leveled field gives a uniform, healthy crop that can compete with } \\
\text { weeds, uses less water, and give higher yields. }\end{array}$ \\
\hline $\mathrm{v}$. & Plant on time & $\begin{array}{l}\text { The best time to plant (Transplant/direct seeding) depends on the locality, rice ecosystem, } \\
\text { soil type, and topography. Transplanting/seeding on time is very important because } \\
\text { late/early planting reduces rice yield and interrupt cropping systems. }\end{array}$ \\
\hline vi. & $\begin{array}{l}\text { Monitoring and } \\
\text { surveillance and } \\
\text { following weather- } \\
\text { based forecasting }\end{array}$ & $\begin{array}{l}\text { Time to time monitoring and surveillance will help the rice plant to remain free from } \\
\text { nutrient disorder, weeds, insect, and disease and keep free from any kind of natural } \\
\text { disaster. }\end{array}$ \\
\hline vii. & Timely weeding & $\begin{array}{l}\text { Weeds compete directly with the rice plants and reduce rice yield. Each one } \mathrm{kg} \text { dry matter } \\
\text { of weeds is equivalent to one } \mathrm{kg} \text { grain loss. Weeds cause most yield loss within the first } 20- \\
50 \text { days after crop establishment. Weeding after panicle initiation may also be important to } \\
\text { prevent weeds shedding seeds in future crops. }\end{array}$ \\
\hline viii. & $\begin{array}{l}\text { Fertilize timely and } \\
\text { effectively }\end{array}$ & $\begin{array}{l}\text { The amount and type of fertilizer applied are determined on the assumption that one ton of } \\
\text { grain will remove } 15 \mathrm{~kg} \text { nitrogen }(\mathrm{N}), 2-3 \mathrm{~kg} \text { phosphorus }(\mathrm{P}) \text {, and } 15-20 \mathrm{~kg} \text { potassium }(\mathrm{K}) \text {. } \\
\text { These base rates need to be modified according to the soil type, the season, the crop } \\
\text { condition, prevailing weather conditions, and efficiency of the application. }\end{array}$ \\
\hline ix. & $\begin{array}{l}\text { Use } \\
\text { efficiently }\end{array}$ & $\begin{array}{l}\text { Manage water in rice field efficiently. Because Good water control increases rice yields and } \\
\text { grain quality as well as improving the efficiency of other inputs such as fertilizer, herbicide, } \\
\text { and pesticides. }\end{array}$ \\
\hline $\mathrm{x}$. & $\begin{array}{l}\text { Control pests and } \\
\text { diseases effectively }\end{array}$ & $\begin{array}{l}\text { If there are pest or disease incidences in the rice field, it is important to diagnose the } \\
\text { problem accurately. For help with the diagnosis, seek advice from a professional. If decided } \\
\text { to apply chemicals, carefully read and follow the instruction of labels. }\end{array}$ \\
\hline xi. & Harvest on time & $\begin{array}{l}\text { Harvesting the crop on time is very important to maximize yields and grain quality. } \\
\text { Harvest when grain moisture is between } 20-22 \% ; 80-85 \% \text { of the grains are straw-colored; } \\
\text { grains in the lower part of the panicle are hard, not soft; and grains are firm but not easily } \\
\text { broken when squeezed between the teeth. }\end{array}$ \\
\hline xii. & Store safely & $\begin{array}{l}\text { Rice is best stored as paddy because the husk provides some protection against insects and } \\
\text { helps prevent grain quality deterioration. Stored rice maintain }<14 \% \text { moisture for grain and } \\
12 \% \text { for seed using bags / drams or in following other methods. }\end{array}$ \\
\hline xiii. & Mill efficiently & $\begin{array}{l}\text { Milling rice paddy removes the husk and bran layer to produce white rice. Rice is best } \\
\text { milled at } 13-14 \% \text { moisture content. milling properly to get optimum head rice. }\end{array}$ \\
\hline xiv. & $\begin{array}{l}\text { Understand } \\
\text { market }\end{array}$ & $\begin{array}{l}\text { The value of milled rice in the market is determined by variety and a number of physical } \\
\text { and chemical characteristics of the variety and the consumers, which will vary within and } \\
\text { between countries. }\end{array}$ \\
\hline
\end{tabular}


Table 7. Stagewise agronomic management consideration for obtain higher yield.

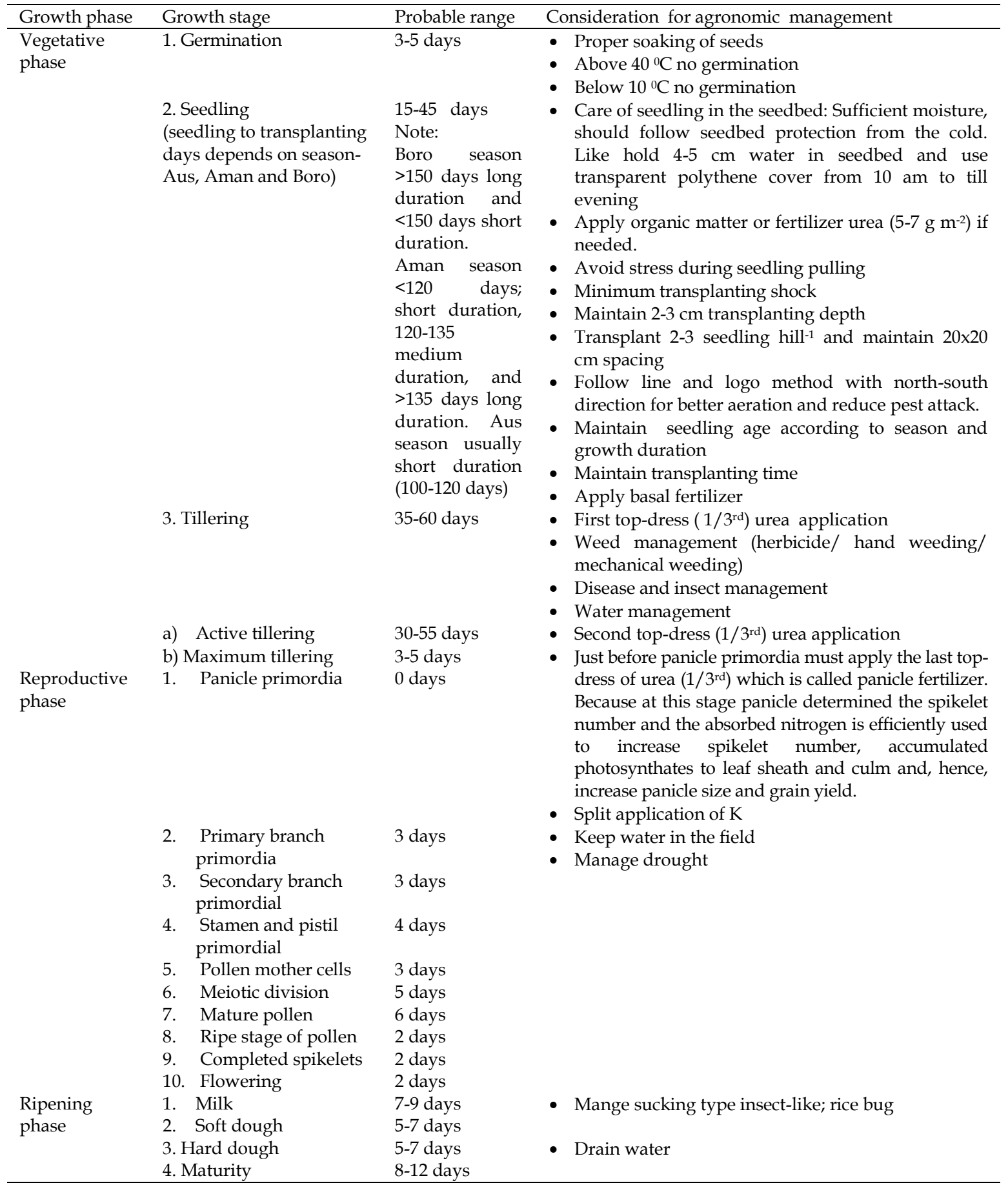

Source: Yoshida, 1981; BRRI (2019)

174 Bhuiyan et al. 
A framework was formulated by using different tools and techniques through literature, review, and experience (Fig. 6). This is the output of SAM-i. The screening will be done from the framework by experience, brainstorming, and group discussion. This is SAM-ii. It will calibrate and validate a technology through laboratory testing, nethouse, and field evaluation of SAM-ii. It may need a multilocation trial especially to the location where the SAM will be applied.After fulfillment of all targets, it may not be work. Again we have to do the same process (Fig. 6). Mature technology must go to the farmers' field in the respective domain for demonstration and training (Fig. 6).
To fulfill SDGs goals and beyond Table 9 indicates how these action plans will work after 2030 to 2050 . The action will be followed thereafter and when necessary research and development studies will be going on.Table $9 \mathrm{a}$, $9 b$, and $9 c$ indicate rice stagewise research and management for primary level, intermediate level, and maturation level which will be followed up during the next period of 2030 to 2050. In addition, in each level of the research and development phase, have some specific action plans (Tables 9a, 9b and 9c). All these smart agronomic management practices will depend on rice growth phases and stages, and it will be implemented by variety, season, location, and ecosystem-based.

Table 8. Location, variety and site-specific smart agronomic management: action plan for each SABM (Stagewise Agronomic Broad Management).

\begin{tabular}{|c|c|c|c|}
\hline Programme & Phase & Stage & Action \\
\hline \multirow{4}{*}{$\begin{array}{l}\text { Research and Development } \\
\text { (Broad Agronomic Management) } \\
\text { - Ensure desired germination (BM1) } \\
\text { - Location, variety and site-specific } \\
\text { sowing and transplanting time } \\
\text { (BM2) } \\
\text { - Seedling age at transplanting } \\
\text { (BM3) } \\
\text { - Top dressing fertilizer (BM4) } \\
\text { (climate specific) } \\
\text { - Top dressing fertilizer (BM4) } \\
\text { (climate specific) } \\
\text { - Water management (BM5) } \\
\text { - Harvesting (BM6) }\end{array}$} & Vegetative & VP1-VP4 & $\begin{array}{ll}\text { o } & \text { Framework development } \\
\text { o } & \text { Screening } \\
\circ & \text { Calibration } \\
\circ & \text { Validation } \\
\circ & \text { Mature SAM ( Smart Agronomic Management) }\end{array}$ \\
\hline & \multirow[t]{2}{*}{ Reproductive } & RP1 & \begin{tabular}{|ll} 
o & Framework development \\
0 & Screening \\
0 & Calibration \\
0 & Validation \\
$\circ$ & Mature SAM \\
\end{tabular} \\
\hline & & RP2-RP10 & $\begin{array}{ll} & \text { Validation } \\
\circ & \text { Mature SAM }\end{array}$ \\
\hline & Follow up & $\mathrm{CO}$ & $\begin{array}{l}\text { Continuous observations to keep on notice if } \\
\text { changes happening on the smart agronomic } \\
\text { management package. If the technologies work } \\
\text { well, it will be continue, if not works well, } \\
\text { SAM will be reviewed. If review not possible } \\
\text { either hold the SAM and start from screening } \\
\text { to validation }\end{array}$ \\
\hline \multirow[b]{2}{*}{ Dissemination } & Phase-1 & Training & o Training (DAE officers and lead farmers) \\
\hline & Phase-2 & Demo & $\begin{array}{llll}\text { Demonstration } & \begin{array}{l}\text { (Different locations } \\
\text { recommended domain) }\end{array}\end{array}$ \\
\hline
\end{tabular}




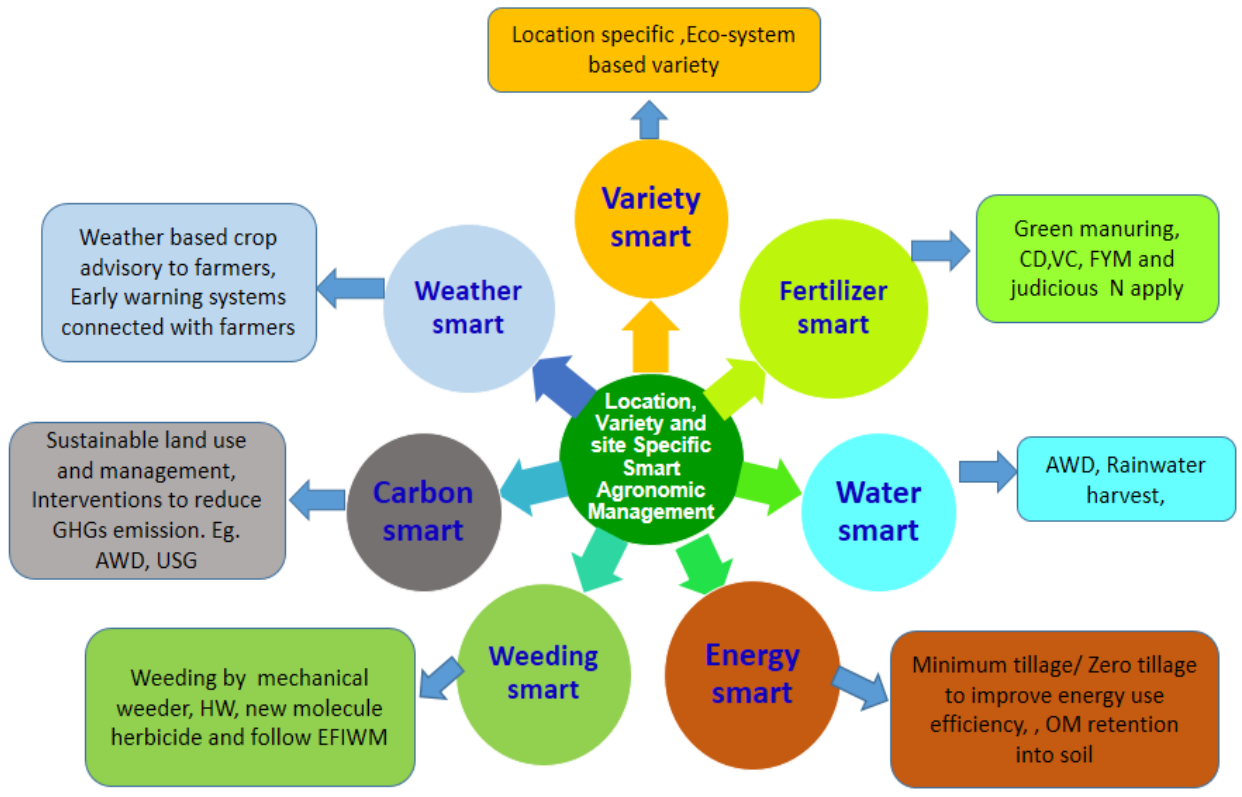

Fig. 5. Smart agronomic management.

\section{Tools and techniques}

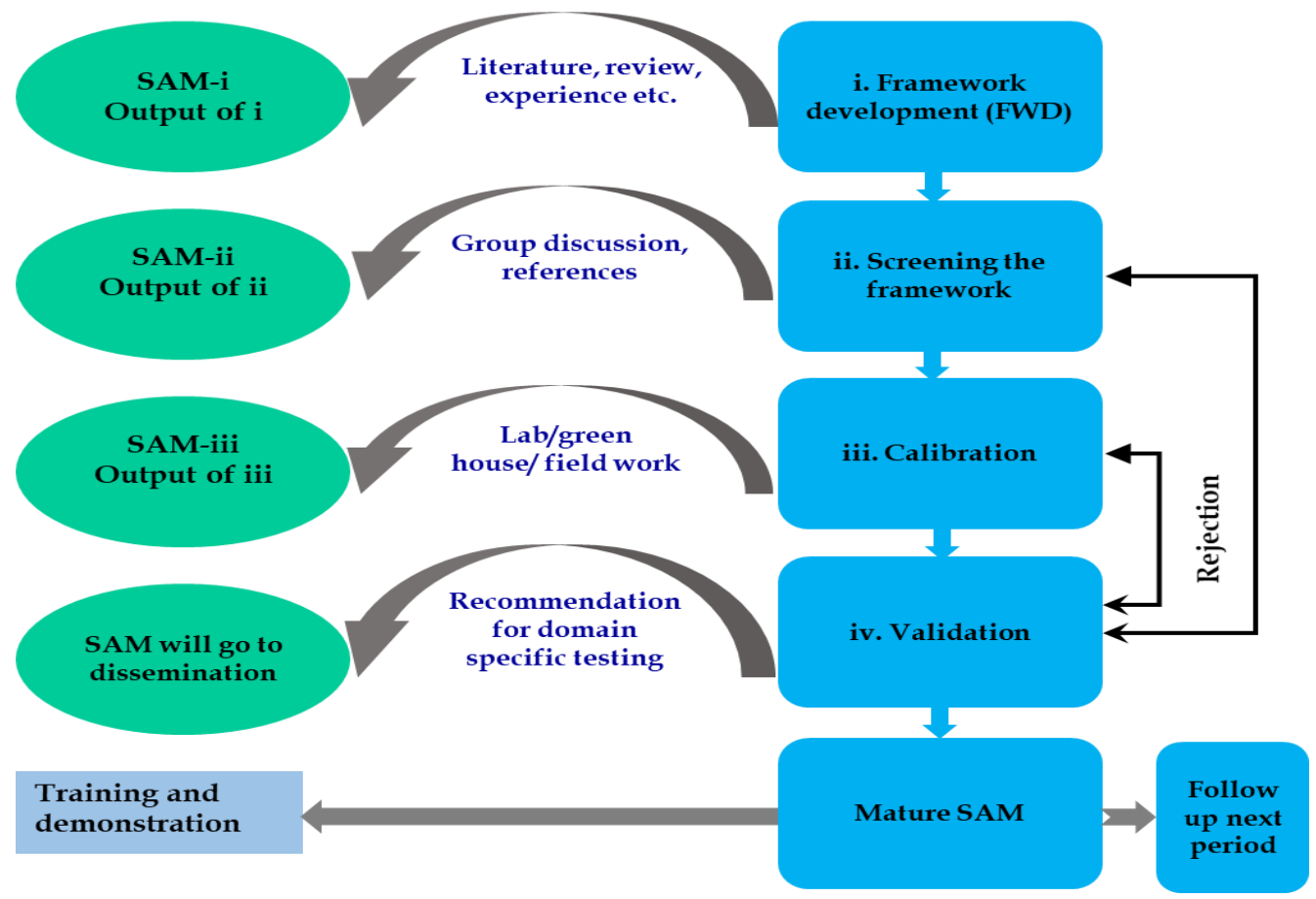

Fig. 6. Flow diagram for implementing action plan of each SABM (Stagewise Agronomic Broad Management). 
Table 9 Variety and location-wise smart agronomic management from the period 2021-2030, 2031-2040 and 2041-2050.

a) Period 2021-2030

\begin{tabular}{|c|c|c|c|c|c|c|c|c|c|}
\hline \multirow{4}{*}{$\begin{array}{l}\text { Rice } \\
\text { growth } \\
\text { phase and } \\
\text { stages }\end{array}$} & \multicolumn{8}{|c|}{ Variety and location wise smart agronomic management } & Period: 2021-2030 \\
\hline & \multicolumn{7}{|c|}{ Research and development phase } & \multicolumn{2}{|c|}{ Dissemination phase } \\
\hline & \multicolumn{2}{|c|}{ Primary } & \multicolumn{2}{|c|}{ Intermediate } & \multicolumn{2}{|c|}{ Maturation } & \multirow{2}{*}{$\begin{array}{l}\text { Follow up } \\
\mathrm{CO}\end{array}$} & \multirow{2}{*}{$\begin{array}{l}\text { Step-1 } \\
\text { Train }\end{array}$} & \multirow{2}{*}{\begin{tabular}{|l|} 
Step-2 \\
Demo
\end{tabular}} \\
\hline & FWD & \begin{tabular}{|l}
$\begin{array}{l}\text { Scree- } \\
\text { ning }\end{array}$ \\
\end{tabular} & $\begin{array}{l}\text { Calibr- } \\
\text { ation }\end{array}$ & $\begin{array}{l}\text { Valid- } \\
\text { ation }\end{array}$ & $\begin{array}{l}\text { Cali- } \\
\text { Valid } \\
\end{array}$ & \begin{tabular}{|l} 
Mature \\
SAM \\
\end{tabular} & & & \\
\hline \multicolumn{10}{|l|}{ VP1 } \\
\hline \multicolumn{10}{|l|}{ VP2 } \\
\hline \multicolumn{10}{|l|}{ VP3 } \\
\hline \multicolumn{10}{|l|}{ VP4 } \\
\hline \multicolumn{10}{|l|}{ RP1 } \\
\hline \multicolumn{10}{|l|}{ RP2-10 } \\
\hline \multicolumn{10}{|l|}{ RIP1-2 } \\
\hline RIP-4 & & & & & & & & & \\
\hline
\end{tabular}

b) Period 2031-2040: Follow up SAM

\begin{tabular}{|c|c|c|c|c|c|c|c|c|c|}
\hline \multirow{4}{*}{$\begin{array}{l}\text { Rice } \\
\text { growth } \\
\text { phase and } \\
\text { stages }\end{array}$} & \multicolumn{9}{|c|}{ Variety and location wise smart agronomic management } \\
\hline & \multicolumn{7}{|c|}{ Research and development phase } & \multicolumn{2}{|c|}{ Dissemination phase } \\
\hline & \multicolumn{2}{|c|}{ Primary } & \multicolumn{2}{|c|}{ Intermediate } & \multicolumn{2}{|c|}{ Maturation } & \multirow{2}{*}{$\frac{\text { Follow up }}{\mathrm{CO}}$} & \multirow{2}{*}{$\begin{array}{l}\text { Step-1 } \\
\text { Train }\end{array}$} & \multirow{2}{*}{\begin{tabular}{|l|} 
Step-2 \\
Demo
\end{tabular}} \\
\hline & FWD & $\begin{array}{l}\text { Scree- } \\
\text { ning }\end{array}$ & $\begin{array}{l}\text { Calibr- } \\
\text { ation }\end{array}$ & $\begin{array}{l}\text { Valid- } \\
\text { ation }\end{array}$ & $\begin{array}{l}\text { Cali- } \\
\text { Valid }\end{array}$ & $\begin{array}{l}\text { Mature } \\
\text { SAM }\end{array}$ & & & \\
\hline \multicolumn{10}{|l|}{ VP1 } \\
\hline \multicolumn{10}{|l|}{ VP2 } \\
\hline \multicolumn{10}{|l|}{ VP3 } \\
\hline \multicolumn{10}{|l|}{ VP4 } \\
\hline \multicolumn{10}{|l|}{ RP1 } \\
\hline \multicolumn{10}{|l|}{ RP2-10 } \\
\hline \multicolumn{10}{|l|}{ RIP 1-2 } \\
\hline RIP-4 & & & & & & & & & \\
\hline
\end{tabular}

c) Period 2041-2050: Follow up of SAM

\begin{tabular}{|c|c|c|c|c|c|c|c|c|c|}
\hline \multirow{5}{*}{$\begin{array}{l}\text { Rice } \\
\text { growth } \\
\text { phase and } \\
\text { stages }\end{array}$} & \multicolumn{9}{|c|}{ Variety and location wise smart agronomic management } \\
\hline & \multicolumn{9}{|c|}{ Period: 2041-2050 } \\
\hline & \multicolumn{7}{|c|}{ Research and development phase } & \multicolumn{2}{|c|}{ Dissemination phase } \\
\hline & \multicolumn{2}{|c|}{ Primary } & \multicolumn{2}{|c|}{ Intermediate } & \multicolumn{2}{|c|}{ Maturation } & \multirow{2}{*}{$\begin{array}{l}\text { Follow up } \\
\mathrm{CO}\end{array}$} & \multirow{2}{*}{$\begin{array}{l}\text { Step-1 } \\
\text { Train }\end{array}$} & \multirow{2}{*}{\begin{tabular}{|l} 
Step-2 \\
Demo \\
\end{tabular}} \\
\hline & FWD & Screening & Calibration & $\begin{array}{l}\text { Validatio } \\
\mathrm{n}\end{array}$ & $\begin{array}{l}\text { Cali- } \\
\text { Valid }\end{array}$ & $\begin{array}{l}\text { Mature } \\
\text { SAM }\end{array}$ & & & \\
\hline \multicolumn{10}{|l|}{ VP1 } \\
\hline \multicolumn{10}{|l|}{ VP2 } \\
\hline \multicolumn{10}{|l|}{ VP3 } \\
\hline \multicolumn{10}{|l|}{ VP4 } \\
\hline \multicolumn{10}{|l|}{ RP1 } \\
\hline \multicolumn{10}{|l|}{ RP2-10 } \\
\hline \multicolumn{10}{|l|}{ RIP 1-2 } \\
\hline RIP-4 & & & & & & & & & \\
\hline
\end{tabular}




\section{CONCLUSION}

The productivity of rice varies not only in a different region but also within the same region depending upon different rice ecologies and production systems used. The intervention of modern varieties coupled with improved agronomic practices can result in reduction of the yield gap. Bridging the yield gap would not be easy given the agroecological and socio-economic diversity prevailing in the country. Research emphasis should be given on improving nutrient use efficiencies, optimum sowing and transplanting schedule with seedling age, and with special emphasis on site-specific nutrient management in rice and rice-based cropping and farming systems. Innovative approaches involving nano-technologies could be considered for efficient use of fertilizers and pesticides. It is essential, therefore, to promote closer collaboration between research, extension, local authorities, non-governmental organizations (NGOs), and private sectors in order to identify specific constraints to high yield and adopt appropriate technologies and solutions, and take concerted actions into consideration to bridge yield gaps of rice, through participatory approaches.

\section{RECOMMENDATIONS}

- The close collaboration and teamwork between farmers, researchers, extension, and commercial enterprise and industry needs to continue.

- Emphasis to be taken on the production of new crop varieties that offer higher yields but use less water, fertilizer, or other inputs and are more resistant to drought, salinity, heat, submergence, and pests and diseases.

- Need a country-wide massive programme to increase soil organic matter by green manuring, farmyard manure, or any other organic amendments.

\section{ACKNOWLEDGEMENTS}

The authors wish to thank anonymous reviewers for their suggestions, which significantly improved this article.

\section{AUTHORS' CONTRIBUTION}

MKAB generated idea; AKMSI, MARS, MAAM, MUS and MSK coordinated the research; MKAB developed methodology, gathered data, carried out analysis and synthesis; MKAB and MUS provided scientific insights; $M K A B$ did the writings for all versions of the manuscript; MARS, MAAM, MUS and MSK performed critical review and editing; All authors read and approved the final manuscript.

\section{DECLARATION OF INTERESTS}

A version of the paper was published in a book "Doubling Rice Productivity in Bangladesh" in 2020 by the Bangladesh Rice Research Institute (BRRI), Gazipur 1701, Bangladesh to commemorate BRRI's 50 th anniversary. The Bangladesh Rice Journal has prior knowledge of the book publication and does not see any conflict of interest.

\section{REFERENCES}

Ahmed, G J U, J C Biswas, B C Roy, M B Rahman, M S Islam, M A A Mahbub and J K Biswas. 2006. Contribution of seedling age and planting time for bridging yield gap in rice. In: Twenty-first BRRIDAE joint workshop, 19-21 September, BRRI.

Alam, M S, M A Quayum and M A Islam. 2010. Crop Production in the Haor Areas of Bangladesh: Insights from Farm Level Survey. The Agriculturists, 8 (2): 88-97.

BBS(Bangladesh Bureau of Statistics). 2018. Statistical yearbook of Bangladesh 2018. Bangladesh Bureau of Statistics, Statistics and Informatics Division, Ministry of Planning, Government of the People's Republic of Bangladesh.

Banayo, N P, S M Haefele, N V Desamero and Y Kato. 2018. On-farm assessment of site-specific nutrient management for rainfed lowland rice in the Philippines. Field Crops Research, 220: 88-96. 
Bhuiyan, M K A, M M Mahbub, L Nahar and M Z I Baki. 2017. Effect of nitrogen levels and weed management on yield performance of BRRI hybrid dhan3 under AWD irrigation system. Bangladesh Agron. J., 20 (1): 13-24.

BRRI (Bangladesh Rice Research Institute). 2019. Adhunik Dhaner Chash (in Bengali). 96 p.

Cassman, K G, A Dobermann, D T Walters, H Yang. 2003. Meeting cereal demand while protecting natural resources and improving environmental quality. Annual Review of Environment and Resources, 28, 315-358.

De Datta, S K. 1981. Principles and practices of rice production. Wiley-Interscience Publications. New York, USA.

Depeng, W, J Huang, L Nie, F Wang, X Ling, K Cui, Y Li and S Peng. 2017. Integrated crop management practices for maximizing grain yield of doubleseason rice crop. Scientific Reports, 7:38982. DOI: $10.1038 /$ srep38982.

Ding, W, X Xu, P He, S Ullah, J Zhang, Z Cui and W Zhou. 2018. Improving yield and nitrogen use efficiency through alternative fertilization options for rice in China: A meta-analysis. Field Crops Research, 227: 11-18.

Herdt, RW. 1996. Establishing the Rockefeller Foundation's priorities for rice biotechnology research in 1995 and beyond. In: Proceedings of the Third International Rice Genetics Symposium Ed. G.S. Khush. IRRI 1996, pp. 17-30.

IRRI (International Rice Research Institute). 1997. CREMNET. Progress Report for 1996. IRRI, Los Banos, Philippines.

Kabir, M S, M U Salam, A Chowdhury, N M F Rahman, K M Iftekharuddaula, M Rahman, M Rashid, S Dipti, A Islam, M Latif, A Islam, M Hossain, B Nessa, , T Ansari, M Ali and J Biswas. 2015. Rice Vision for Bangladesh: 2050 and Beyond. Bangladesh Rice Journal, 19 (2): 1-18. https://doi .org/ 10.3329/ brj.v19i 2.28160 .

Kabir, M S, M U Salam, A K M S Islam, M A R Sarkar, M A A Mamun, M C Rahman, B Nessa, M J Kabir, H B Shozib, M B Hossain, A Chowdhury, M Nasim, K M Iftekharuddaula, M S Hossain, M K A Bhuiyan, B Karmakar, M S Rahman, M M Haque, M T Khatun, M P Ali, S M H A Rabbi, P L Biswas, E S M H Rashid and N M F Rahman. 2020. Doubling rice productivity in Bangladesh: A way to achieving SDG 2 and moving forward. Bangladesh Rice Journal, 24 (2): $1-47$.
Karim, Z, S G Hussain and M Ahmed. 1990. Salinity problems and crop intensification in the coastal regions of Bangladesh. BARC, Soil Publ., 3 (3): 3-6.

Kamruzzaman, Md and Shaw, Rajib. 2018. Flood and Sustainable Agriculture in the Haor Basin of Bangladesh: A Review Paper. Universal Journal of Agricultural Research. 6. 10.13189/ujar.2018.060106.

Ong Liang-bing, Gong Kai-yuan, Duan Feng-ying , Li Shao-kun, Zhao Ming, He Jian qiang, Zhau wenbin and Yu Qiang. 2021. Yield gap and resource utilization efficiency of three major food crops in the world-A review. Journal of Integrative Agriculture, 20 (2): 349-362.

Pradhan, P, G Fischer, H van Velthuizen, D E Reusser and J P Kropp. 2015. Closing yield gaps: How sustainable can we be?. PloS one, 10 (6): e0129487.

Rehman A., A Ullah, F Nadeem, M Farooq. (2019) Sustainable Nutrient Management. In: M Farooq, M Pisante. (eds) Innovations in Sustainable Agriculture. Springer, Cham.

Rong, L B, K Y Gong, F Y Duan, S K Li, M Zhao, J Q He, W B Zhou and Q Yu. 2021. Yield gap and resource utilization efficiency of three major food crops in the world -A review. Journal of Integrative Agriculture, 20: 349-362.

Salam, M A, K M Iftekharuddaula, A B Siddique, M A Rashid, M H Rashid, M S I Momin, M S Kabir and J K Biswas. 2014. Strategic Plan for Increasing Aus and Aman Rice Cultivation in Bangladesh. In: conference paper. DOI: 10.13140/2.1.346 1.5684.

Salam, M U, M A Kader, M A Jalil Mridha, A K M Ruhul Amin, N A Khandaker, A K Das, M H Rashid and M $S$ Kabir. 2016: Agronomic vision and roadmap for Bangladesh Agriculture through to 2050. In proceedings of $15^{\text {th }}$ conference of Bangladesh Society of Agronomy, Bangladesh Agricultural University, Mymensingh.

Sattar, S A. 2000: Bridging the rice yield gap in Bangladesh. In: "Bridging the rice yield gap in the Asia-Pacific region". Edited by Minas K. Papademetriou, Frank J. Dent and Edward M. Herath. In proceeding of Food and agriculture organization of the united nations regional office for Asia and the Pacific, Bangkok, Thailand, pp. 54-61.

Shelley, I J, Misuzu Takahashi-Nosaka, Mana KanoNakata, Mohammad S. Haque and Yoshiaki Inukai .2016.Rice Cultivation in Bangladesh: Present Scenario, Problems, and Prospects. J Intl Cooper Agric Dev. 14: 20-29

Stuart, A M, A R Pame, D Vithoonjit, L Viriyangkura, J Pithuncharurnlap, N Meesang, P Suksiri, G R 
Singleton and R M Lampayan. 2018. The application of best management practices increases the profitability and sustainability of rice farming in the central plains of Thailand. Field Crops Research, 220: 78-87.

UNEP (United Nations Environment Program). 2001. Follow-up study of the health effects of the Easter 1998 flooding in Banbury and Kadlington. Report to the environment agency. Enfield: Flood Hazard Research Centre. UNEP, Bangladesh.

Van Ittersum, M K, K G Cassman, P Grassini, J Wolf, P Tittonell and Z Hochman. 2013. Yield gap analysis with local to global relevance -A review. Field Crops Research, 143: 4-17.

\section{Acronyms and Abbreviations}

BRRI = Bangladesh Rice Research Institute

BINA= Bangladesh Institute of Nuclear Agriculture

T. Aman $=$ Transplanted Aman rice

IRRI= International Rice Research Institute

SAM= Smart Agronomic Management

SABM= Stagewise Agronomic Broad Management

DAE $=$ Department of Agricultural Extension

$\mathrm{GO}=$ Government organization

ICM = Integrated crop management

IPM = Integrated pest management

$\mathrm{NGO}=$ Non-government organization

SDG $=$ Sustainable development goal

$\mathrm{BMP}=$ Best management practices

ICMA= Integrated crop management plan

ICM= Integrated crop management

DAS $=$ Days after sowing

$\mathrm{DAT}=$ Days after transplanting

$\mathrm{DAP}=$ Days after planting

CREMNET $=$ Crop and Resource Management Network

$\mathrm{DAE}=$ Department of Agriculture Extension

$\mathrm{SM}=$ Smart management

FWD = Frame work development

Mtg-FWK = Management framework

Cali-Valid $=$ Calibration and validation

Sm-Mtg = Smart management

$\mathrm{CO}=$ Continuous obervation

Train $=$ Training

Demo $=$ Demonstration
Yoshida, S. 1981. Fundamentals of rice crop science. International Rice Research Institute, Philippines.

Zhang, H, Y Chao, K Xiangsheng, H Danping, G Junfei, L Lijun, W Zhiqin and Y Jianchang. 2018. Progressive integrative crop managements increase grain yield, nitrogen use efficiency and irrigation water productivity in rice. Field crop research, 215: 1-11.

Wen-bin, Z and D Feng-ying. 2021. Closing crop yield and efficiency gaps for food security and sustainable agriculture. Journal of Integrative Agriculture, 20 (2): 343-348 
Rice growth phases and stages related Acronyms and Abbreviations

\begin{tabular}{|l|l|l|l|}
\hline Growth phase & Growth stage & Symbolic name & Abbreviation \\
\hline \multirow{5}{*}{ Vegetative phase } & 1. Germination & Vegetative phase 1 & VP1 \\
\cline { 2 - 4 } & 2. Seedling & Vegetative phase2 & VP2 \\
\cline { 2 - 4 } & 3a. Active Tillering & Vegetative phase 3 & VP3 \\
\cline { 2 - 4 } & 3b. Maximum tillering & Vegetative phase 4 & VP4 \\
\hline \multirow{5}{*}{ Reproductive phase } & 1. Panicle primodia & Reproductive phase1 & RP1 \\
\cline { 2 - 4 } & 2. Primary branch primodia & Reproductive phase2 & RP2 \\
\cline { 2 - 4 } & 3. Secondary branch primordia & Reproductive phase3 & RP3 \\
\cline { 2 - 4 } & 4. Stamen and pistil primordia & Reproductive phase4 & RP4 \\
\cline { 2 - 4 } & 5. Pollen mother cells & Reproductive phase5 & RP5 \\
\cline { 2 - 4 } & 6. Meiotic division & Reproductive phase6 & RP6 \\
\cline { 2 - 4 } & 7. Mature pollen & Reproductive phase7 & RP7 \\
\cline { 2 - 4 } & 8. Ripe stage of pollen & Reproductive phase8 & RP8 \\
\cline { 2 - 4 } & 9. Completed spikelets & Reproductive phase9 & RP9 \\
\cline { 2 - 4 } & 10. Flowering & Reproductive phase10 & RP10 \\
\hline \multirow{5}{*}{ Ripening phase } & 1. Milk stage & Ripening phase1 & Rip1 \\
\cline { 2 - 4 } & 2. Soft dough & Ripening phase2 & Rip2 \\
\cline { 2 - 4 } & 3. Hard dough & Ripening phase3 & Rip3 \\
\cline { 2 - 4 } & 4. Maturity stage & Ripening phase4 & Rip4 \\
\hline
\end{tabular}


182 Bhuiyan et al. 